\title{
Trichuris sp. from 1,040 +/- 50-year-old Cervidae coprolites from the archaeological site Furna do Estrago, Pernambuco, Brazil
}

\author{
Luciana Sianto, Antônio Nascimento Duarte, Marcia Chame, Juliana Magalhães, \\ Mônica Vieira de Souza, Luiz Fernando Ferreira, Adauto Araújo/ ${ }^{+}$ \\ 'Escola Nacional de Saúde Pública Sergio Arouca-Fiocruz, Rua Leopoldo Bulhões 1480, 21041-210 Rio de Janeiro, RJ, Brasil
}

We present results of the paleoparasitological analysis of Cervidae coprolites that were recovered from the archaeological site Furna do Estrago, Pernambuco, Brazil. Trichuris sp. eggs were recovered from the coprolite samples dated 1,040 \pm 50 years before present. This is the first record of Trichuris $s p$. in semiarid Cervidae, unexpectedly recorded in archaeological material.

Key words: Cervidae - coprolites - paleoparasitology

The archaeological site Furna do Estrago was used as a dwelling and burial place by prehistoric populations during different periods between 9,000-2,000 years before present (BP). This site is located in an upland forest in northeastern Brazil, a mesic enclave in a semiarid region in the state of Pernambuco. Currently, the average annual temperature in the region is $20.4^{\circ} \mathrm{C}$, with highs of $29.6^{\circ} \mathrm{C}$ in November and December and lows of $16.6^{\circ} \mathrm{C}$ during July and August (Lima 1985).

During excavations performed in 1982 by a team from the Catholic University of Pernambuco and conducted by archaeologist Jeannette Lima, 86 coprolites were collected. The coprolites were sent to our Laboratory of Paleoparasitology and three were identified by shape and size as belonging to the family Cervidae, probably Mazama or Ozotoceros. Blastocerus was ruled out based on the pellet size (JMB Duarte, unpublished observation). Ozotoceros and Mazama faeces are identical in size and shape. Therefore, a more accurate species assignment could not be achieved.

Because of their small size no fragments were taken and the coprolites were rehydrated in an aqueous $0.5 \%$ trisodium phosphate solution for $72 \mathrm{~h}$ (Callen \& Cameron 1960). After this period, the samples were sieved through thrice-folded gauze for spontaneous sedimentation (Lutz 1919) as recommended by Araujo et al. (1989). The sediment obtained was prepared for observation under an optical microscope at $100 \mathrm{X}$ and 400X magnifications.

Three coprolites from different layers were examined. One of the coprolites dated $1,040 \pm 50$ years BP (Lima 1985) was positive for Trichuris sp. eggs (Figure). The average size of the eggs (length $\mathrm{x}$ width) was $63.36 \mu \mathrm{m}$ [standard deviation (SD) 4.92] x $33.92 \mu \mathrm{m}$ (SD 1.68) $(n=20)$. The range in the length with the polar

Financial support: CNPq, FAPERJ

+Corresponding author: adauto@ensp.fiocruz.br

Received 11 May 2011

Accepted 13 September 2011 plugs and the range in the width were 53.28-69.93 $\mu \mathrm{m}$ x 29.97-36.63 $\mu \mathrm{m}$, respectively.

Trichuris ovis has been found in Alces alces, Capreolus capreolus and Cervus elaphus in Belarusian Polesie and in Scotland (Shimalov \& Shimalov 2003, Irvine et al. 2006). Trichuris sp. has been documented in $C$. elaphus and Dama dama in Portugal (Maia 2001). Trichuris capreoli has been found in Cervidae, but no genus or location were reported (Taylor et al. 2010). In the Americas, Trichuris sp. has been found parasitizing Odocoileus virginianus in the United States (Nascimento et al. 2000) and Mexico (Montes Pérez et al. 1998) and T. ovis has been found in Mazama gouazoubira in Bolivia (Deem et al. 2004). In North America, where $A$. alces arrived across Beringia, there are records of Trichuris discolor and T. ovis, both attributed to domestic livestock (Hoeve et al. 1988).

There are no articles reporting the presence of Trichuris in Mazama americana or Ozotoceros bezoarticus. Trichuris sp. and T. ovis have been found in Blastocerus dichotomus (Muniz-Pereira et al. 2009) with eggs with sizes of 50-80 $\mu \mathrm{m} \times 30-40 \mu \mathrm{m}$ (Pinto 1945) and Trichuris globulosa (Fowler \& Cubas 2001) has been observed with eggs with sizes of 59-69 $\mu \mathrm{m} \times 27-36 \mu \mathrm{m}$ (NEHU 2011). Although the eggs of T. ovis and T. globulosa are similar in size to the eggs observed in this study, these species are parasites of domestic ruminants (Pinto 1945, Vicente et al. 1997) and there is no record of sheep, goat or cattle in this region prior to American colonisation.

Trichuris tenuis has been found in llamas and its eggs are 64 x $32 \mu \mathrm{m}$ (Foreyt \& Foreyt 2001), consistent with the size of the eggs found in this study. However, the only camelid present in northeastern Brazil was Palaeolama spp, which became extinct around 10,000 years BP (Guérin \& Faure 2006). Given the possibility of the occurrence of this parasite in Palaeolama, true infection by this worm in deer and this worm's survival in the region are also possibilities.

Trichuris suis eggs range in size from 46.6-71.2 $\mu \mathrm{m}$ (Beer 1976), which is consistent with those found in the coprolites. However, the natural host of this parasite is the domestic pig (Sus scrofa domestica), which was introduced to the Americas during colonial times. 


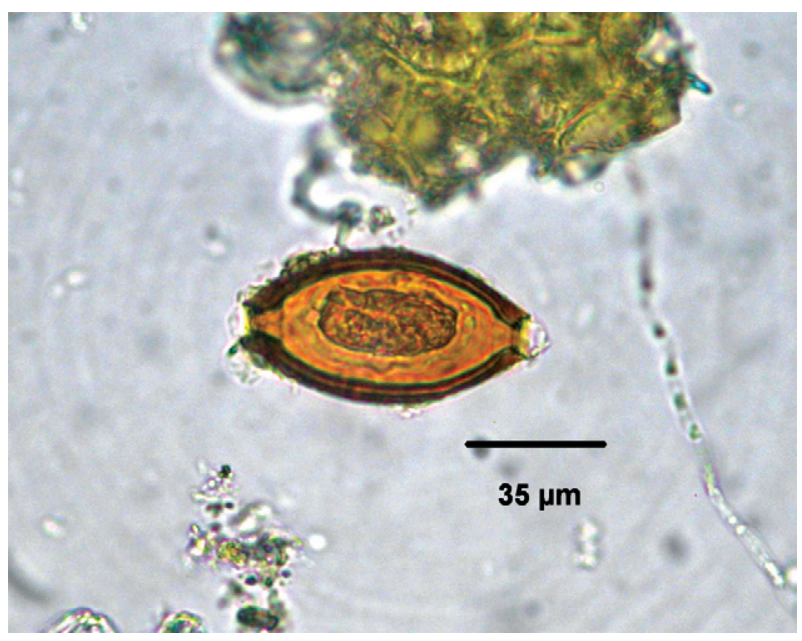

Trichuris sp. egg found in Cervidae coprolites from archaeological site of Furna do Estrago, state of Pernambuco, Brazil.

Eggs of Trichuris trichiura are slightly smaller (50-60 $\mu \mathrm{m} \times 21-25 \mu \mathrm{m}$ ) (Sloss \& Kemp 1978) than those found in deer coprolites. Although deer were probably an important protein source in prehistoric human nutrition (Lima 1985), the possibility that the eggs from the coprolites belong to this species can be ruled out based on the host specificity, which has its origins in a common ancestor of primates and humans that transferred the parasite to humans in the early relationship of these species, as discussed in the review by Confalonieri (1988).

Therefore, the presence of these eggs in archaeological material demonstrates the existence of a previously unknown natural host, dating back 1,000 years and the possible occurrence of a new Trichuris species. The existence of new species of parasites in cervids was previously suggested by paleoparasitology studies, with the discovery of Eimeria sp. in 9,000-year-old cervid coprolites, after confirmation of Eimeria in faeces collected from zoo deer (Ferreira et al. 1992). However, it can not be ruled out that T. tenuis parasitism of modern deer species originated from parasitism of extinct Palaeolama. Host sympatry ended 10,000 BP and the parasite switch may have occurred while both the host and parasite occupied the same environment. Paleoparasitology data, in this case, indicate a possible case of parasitism in an extinct host that has persisted to the present in a sympatric host.

\section{ACKNOWLEDGEMENTS}

To Dr José Maurício Barbanti Duarte (Núcleo de Pesquisa e Conservação de Cervídeos, UNESP), for informations about size of cervid faeces.

\section{REFERENCES}

Araujo AJG, Ferreira LFR, Confalonieri UEC, Chame M, Ribeiro B 1989. Strongyloides ferreirai Rodrigues, Vicente \& Gomes, 1985 (Nematoda, Rhabdiasoidea) in rodent coprolites $(8,000-2,000$ years BP) from archaeological sites from Piaui, Brazil. Mem Inst Oswaldo Cruz 84: 493-496.

Beer RJS 1976. The relationship between Trichuris trichiura (Linnaeus 1758) of man and Trichuris suis of the pig. Res Vet Sci 20: 47-54.
Callen EO, Cameron TWM 1960. A prehistoric diet revealed in coprolites. New Sci 8: 35-40.

Confalonieri UEG 1988. Paleopidemiologia de T. trichiura na América. In LF Ferreira, A Araújo, U Confalonieri (eds.), Paleoparasitologia no Brasil, Editora PEC/ENSP, Rio de Janeiro, p. 120-137.

Deem SL, Noss AJ, VillarroelI R, Uhart MM, Karesh WB 2004. Disease survey of free ranging grey brocket deer (Mazama gouazoubira) in the Gran Chaco, Bolivia. J Wildl Dis 40: 9298.

Ferreira LFR, Araújo AJG, Confalonieri UEG, Chame M, Ribeiro B 1992. Eimeria oocysts in deer coprolites dated from 9,000 years BP. Mem Inst Oswaldo Cruz 87: 105-106.

Foreyt WJ, Foreyt B 2001. Veterinary parasitology reference manual, 5th ed., Wiley-Blackwell, Malden, 235 pp.

Fowler ME, Cubas ZS 2001. Biology, medicine and surgery of South American wild animals, Wiley-Blackwell, Ames, $536 \mathrm{pp}$.

Guérin C, Faure M 2006. La biodiversité mammalienne au Pléistocène supérieur - Holocène ancien dans la région du Parc National Serra da Capivara (SE du Piauí, Brésil). FUMDHAMentos 7: 79-93.

Hoeve J, Joachim DG, Addison EM 1988. Parasites of Moose (Alces alces) from an agricultural area of eastern Ontario. $J$ Wildl Dis 24: $371-374$.

Irvine RJ, Corbishley H, Pilkington JG, Albon SD 2006. Low-level parasitic worm burdens may reduce body condition in free-ranging red deer (Cervus elaphus). Parasitol 133: 465-475.

Lima JMD 1985. Arqueologia da Furna do Estrago, Brejo da Madre de Deus, Pernambuco, Universidade Federal de Pernambuco, Recife, 143 pp.

Lutz A 1919. O Schistosomum mansoni e a schistosomatose segundo observações feitas no Brasil. Mem Inst Oswaldo Cruz 11: 121-155.

Maia MJ 2001. Helmintofauna do veado (Cervus elaphus L.) e do gamo (Dama dama L.) na Tapada Nacional de Mafra. Rev Port Cienc Vet 96: 81-84.

Montes Pérez RC, Rodríguez Vivas RI, Torres Acosta JF, Ek Pech LG 1998. Seguimiento anual de la parasitosis gastrointestinal de venados cola blanca Odocoileus virginianus (Artiodactyla: Cervidae) en cautiverio en Yucatan, Mexico. Rev Biol Trop 46: 821-827.

Muniz-Pereira LC, Vieira FM, Luque JL 2009. Checklist of helminth parasites of threatened vertebrate species from Brazil. Zootaxa 2123: 1-45.

Nascimento AA, Bonuti MR, Mapeli EB, Tebaldi JH, Arantes IG, Zettermann CD 2000. Infecções naturais em cervídeos (Mammalia: Cervidae) procedentes dos estados do Mato Grosso do Sul e São Paulo por nematódeos Trichostrongyloidea Cram, 1927. Bras J Vet Res Anim Sci 37: 153-158.

NEHU - North-Eastern Hill University 2011. Meghalaya: North-Eastern Hill University. Available from: nehu.ac.in.

Pinto C 1945. Zoo - Parasitos de interesse médico e veterinário, Editora Scientífica, Rio de Janeiro, $461 \mathrm{pp}$.

Shimalov VV, Shimalov VT 2003. Helminth fauna of cervids in Belorussian Polesie. Parasitol Res 89: 75-76.

Sloss MW, Kemp RL 1978. Veterinary clinical parasitology, 5th ed., The Iowa State University Press, Iowa, 274 pp.

Taylor MA, Coop RL, Wall RL 2010. Parasitologia Veterinária, Guanabara Koogan, Rio de Janeiro, 742 pp.

Vicente JJ, Rodrigues HO, Gomes DC, Pinto RM 1997. Nematódeos do Brasil. Parte V: Nematódeos de Mamíferos. Rev Bras Zool 14: 1-452. 